\title{
Inhibitory Interneuron Classes Express Complementary AMPA-Receptor Patterns in Macaque Primary Visual Cortex
}

\author{
Roxana N. Kooijmans, ${ }^{1}$ Matthew W. Self, ${ }^{1}$ Floris G. Wouterlood, ${ }^{2}$ Jeroen A.M. Beliën, ${ }^{3}$ and Pieter R. Roelfsema ${ }^{1,4,5}$ \\ ${ }^{1}$ Department of Vision and Cognition, Netherlands Institute for Neuroscience, 1105 BA Amsterdam, The Netherlands, ${ }^{2}$ Section of Functional \\ Neuroanatomy, Department of Anatomy and Neurosciences, ${ }^{3}$ Department of Pathology, Vrije Universiteit Medical Center, 1007 MB Amsterdam, The \\ Netherlands, ${ }^{4}$ Department of Integrative Neurophysiology, Center for Neurogenomics and Cognitive Research, Vrije Universiteit, 1081 HV Amsterdam, The \\ Netherlands, and ${ }^{5}$ Department of Psychiatry, Academisch Medisch Centrum, 1105 AZ Amsterdam, The Netherlands
}

Glutamate receptors mediate excitatory neurotransmission. A very prevalent type of glutamate receptor in the neocortex is the AMPA receptor (AMPAR). AMPARs mediate fast synaptic transmission and their functionality depends on the subunit composition. In primary visual cortex (area V1), the density and subunit composition of AMPARs differ among cortical layers and among cell types. The AMPARs expressed by the different types of inhibitory interneurons, which are crucial for network function, have not yet been characterized systematically. We investigated the distribution of AMPAR subunits in macaque V1 for three distinct subpopulations of inhibitory interneurons: parvalbumin-immunoreactive (PV-IR) interneurons, calbindin-immunoreactive (CB-IR) interneurons, and calretininimmunoreactive (CR-IR) interneurons. We found that PV-IR cells, which have previously been identified as fast spiking, show high expression of the GluA2 and GluA3 subunits. In contrast, CB-IR and CR-IR cells, which tend to be intermediate spiking, show high expression of the GluA1 and GluA4 subunits. Thus, our data demonstrate that the expression of AMPARs divides inhibitory interneurons in macaque V1 into two categories that are compatible with existing classification methods based on calcium-binding proteins and firing behavior. Moreover, our findings suggest new approaches to target the different inhibitory interneuron classes pharmacologically in vivo.

Key words: AMPA; GluA2; interneurons; macaque; quantification; V1

\section{Introduction}

Inhibitory interneurons play a crucial role in controlling the activity of the cortical network. They determine the tuning of excitatory neurons by suppressing their activity via the release of the inhibitory neurotransmitter GABA (Burkhalter, 2008; Isaacson and Scanziani, 2011). In the primary visual cortex, inhibitory interneurons contribute to orientation selectivity (Li et al., 2012) and surround suppression (Adesnik et al., 2012).

There are many types of interneurons and various schemes for classifying them (Burkhalter, 2008). One important classification scheme relies on the differential expression pattern of calciumbinding proteins (CBPs), such as parvalbumin (PV), calbindin (CB), and calretinin (CR). In macaque primary visual cortex (V1), these three proteins identify largely disjoint populations (Van Brederode et al., 1990; Condé et al., 1994; DeFelipe, 1997; Zaitsev et al., 2005; Disney and Aoki, 2008) and together cover $\sim 95 \%$ of the inhibitory population (Defelipe et al., 1999; Disney

\footnotetext{
Received July 20, 2013; revised March 22, 2014; accepted March 26, 2014.

Author contributions: R.N.K. and P.R.R. designed research; R.N.K. performed research; R.N.K., M.W.S., F.G.W., and J.A.M.B. analyzed data; R.N.K., M.W.S., F.G.W., J.A.M.B., and P.R.R. wrote the paper.

The work was supported by a Netherlands Organisation for Scientific Research (NW0) Vici grant (453-06-003), the European Union Seventh Framework Program (Projects 269921 "BrainScaleS" and "ABC," PITN-GA-2008290011), and an NWO Brain and Cognition program grant (433-09-208) awarded to P.R.R. We thank Kor Brandsma, Corbert G. van Eden, Jan Klooster, and Chris Pool for biotechnical assistance.

The authors declare no competing financial interests.

Correspondence should be addressed to Pieter Roelfsema at the above address. E-mail: p.roelfsema@nin.knaw.nl.

DOI:10.1523/JNEUROSCI.3188-13.2014

Copyright $\odot 2014$ the authors $\quad 0270-6474 / 14 / 336303-13 \$ 15.00 / 0$
}

and Aoki, 2008). PV is present in chandelier and basket cells, CB in neurogliaform and Martinotti cells, and CR in double bouquet cells (Condé et al., 1994). These cell types exhibit specific distributions across the layers (Lund, 1987; Lund et al., 1988; Lund and Yoshioka, 1991; Lund and Wu, 1997). Accordingly, the expression of CBPs reveals a clear laminar profile (Fig. 1).

Glutamate receptors mediate the excitatory input of inhibitory interneurons. We focused on AMPA receptors (AMPARs), which are the predominant and fast-acting class of glutamate receptors. Four AMPAR subunits have been characterized. These subunits, GluA1 through GluA4, are expressed by excitatory and inhibitory neurons in macaque V1 (Carder and Hendry, 1994; Carder, 1997). The subunit composition of individual AMPARs determines their permeability for sodium, potassium, and calcium ions. Only a subset of all possible GluA1 through GluA4 combinations are expressed (Wenthold et al., 1996) and of these, AMPARs containing the GluA2 subunit are impermeable for $\mathrm{Ca}^{2+}$ (Lerma et al., 1994). Furthermore, different AMPAR subunits play distinct roles in synaptic plasticity (Kessels and Malinow, 2009). Only a few pharmacological compounds discriminate between the subunits (Strømgaard et al., 2005), which impedes electrophysiological approaches to assess their contribution to the excitatory drive of GABAergic cells. Previous studies used immunohistochemistry and electron microscopy to demonstrate that the GluA2 subunit is expressed by GABAergic neurons (He et al., 2001), but not by interneurons expressing CB or CR (Ryoo et al., 2003). However, a systematic study of all AMPAR 

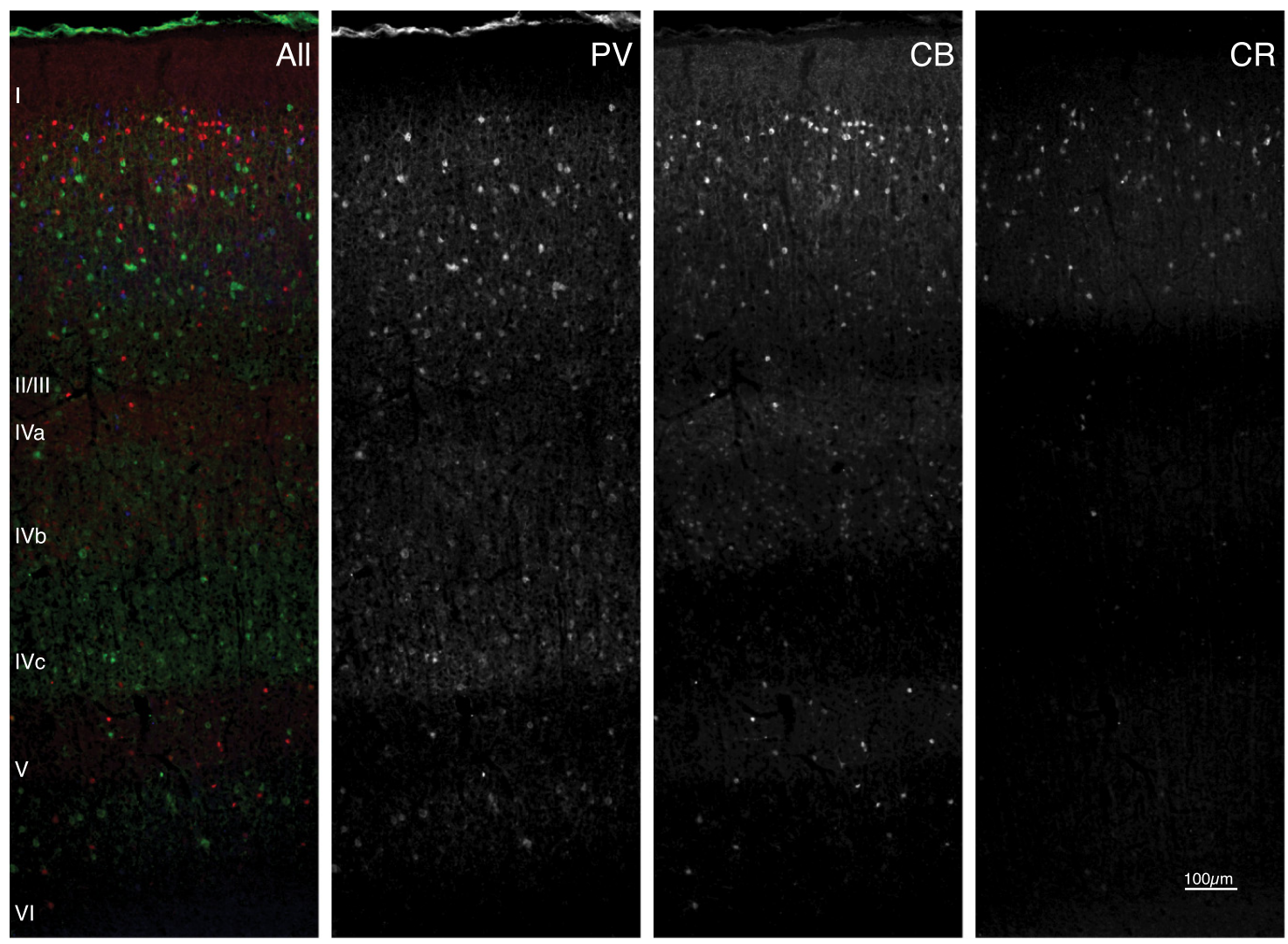

Figure 1. Laminar profiles of PV (green), CB (red), and CR (blue) immunoreactivity. Epifluorescence image from a triple-stained 20- $\mu$ m-thick macaque V1 section. Most PV-IR cell bodies are located in layer II/III, layer IVc, and layer VI. CB-IR cell bodies are visible in layers II/III and layer IVb. CR-IR cell bodies are present in layer II/III. There is no overlap between the three cell populations, and the laminar distributions differ among CBPs.

Table 1. Overview of the antibodies used in the study, including the primary antibodies, the corresponding control peptides, as well the $\mathrm{F}\left(\mathrm{ab}^{\mathrm{\prime}}\right)_{2}$ and fluorescent antibodies

\begin{tabular}{|c|c|c|c|c|c|c|}
\hline Antigen & Control peptide & Primary antibody & Antibody species & $F\left(a b^{b}\right)_{2}$ antibody & $\mathrm{F}\left(\mathrm{ab}^{\prime}\right)_{2}$ species & Fluorophore [fluorphore species] \\
\hline PV & Abcam ab45541 & Swant PV 235 & $M(a) P V$ & $\begin{array}{l}\text { Jackson ImmunoResearch } \\
\text { 315-006-003 }\end{array}$ & $\mathrm{R}(\mathrm{a}) \mathrm{M}$ & $\begin{array}{l}\text { Molecular Probes Invitrogen } \\
\qquad A-31570^{a}[D(a) M], A-31572^{a}[D(a) R],\end{array}$ \\
\hline CB & Abcam ab60452 & Swant CB 38 & $R(a) C B$ & Jackson ImmunoResearch & $G(a) R$ & $\mathrm{~A}-21432^{a}[\mathrm{D}(\mathrm{a}) \mathrm{G}]$ \\
\hline CR & Abcam ab73479 & Chemicon AB5054 & $R(a) C R$ & $111-006-003$ & & \\
\hline GluA1 & Abcam ab28424 & Chemicon AB1504 & R(a)GluA1 & - & - & Molecular Probes Invitrogen \\
\hline GluA2 & Abcam ab25708 & Chemicon MAB397 & $\mathrm{M}(\mathrm{a}) \mathrm{GluA2}$ & - & - & $\mathrm{A}-21206^{b}[\mathrm{D}(\mathrm{a}) \mathrm{R}], \mathrm{A}-21202^{b}[\mathrm{D}(\mathrm{a}) \mathrm{M}]$ \\
\hline GluA3 & Abcam ab132969 & Chemicon MAB5416 & M(a)GluA3 & - & - & \\
\hline GluA4 & Abcam ab152441 & Upstate 06-308 & R(a)GluA4 & - & - & \\
\hline
\end{tabular}

Untagged $\mathrm{F}\left(\mathrm{ab}^{\mathrm{I}}\right)_{2}$ antibodies were used to block same-species primary antibodies. The $\mathrm{F}\left(\mathrm{ab}^{\mathrm{I}}\right)_{2}$ and fluorescent antibodies used depended on the primary antibody species, as described in Materials and Methods. The species are indicated in capital letters, with $M$ for mouse, $R$ for rabbit, $G$ for goat, and D for donkey.

${ }^{a}$ AlexaFluor 555 .

${ }^{b}$ AlexaFluor 488 .

subunits expressed by the different classes of interneurons has been lacking. We therefore used immunohistochemistry and confocal microscopy to visualize CBPs and AMPAR subunits in macaque V1, capitalizing on a new quantitative image analysis method to measure colocalization (Wouterlood et al., 2008; Beliën and Wouterlood, 2012).

We report that PV-immunoreactive (PV-IR) cells express high concentrations of the GluA2 and GluA3 subunits, whereas CB-immunoreactive (CB-IR) and CR-immunoreactive (CR-IR) cells express high concentrations of the GluA1 and GluA4 subunits. These results imply that the AMPARs of fast-spiking PV-IR cells are largely impermeable to $\mathrm{Ca}^{2+}$. In contrast, the AMPARs of CB/CR-IR cells result in a stronger influx of $\mathrm{Ca}^{2+}$. Furthermore, our results suggest that drugs that are selective for GluA2- lacking AMPARs can be used to specifically target CB-IR and CR-IR cells in vivo.

\section{Materials and Methods}

Fixation and sectioning. We used samples from two adult male macaque monkey (Macaca mulatta) brains, monkeys A and R. The animals were killed and perfused transcardially, first with phosphate-buffered $4 \%$ formaldehyde solution, followed by buffered $5 \%$ sucrose, both with $\mathrm{pH}$ 7.6, at room temperature. After extraction, the brains were placed successively in 12.5 and $25 \%$ buffered sucrose solutions, at $4^{\circ} \mathrm{C}$, until equilibrium, to prevent subsequent cryodamage. They were subsequently grossly sectioned; from each brain two blocks were extracted from the right occipital lobe, posterior to the lunate sulcus, to allow later cryostat sectioning. The brains were then shock-frozen and stored at $-80^{\circ} \mathrm{C}$. Several weeks later, we cut occipital lobe blocks into $20-\mu \mathrm{m}$-thick sagittal 

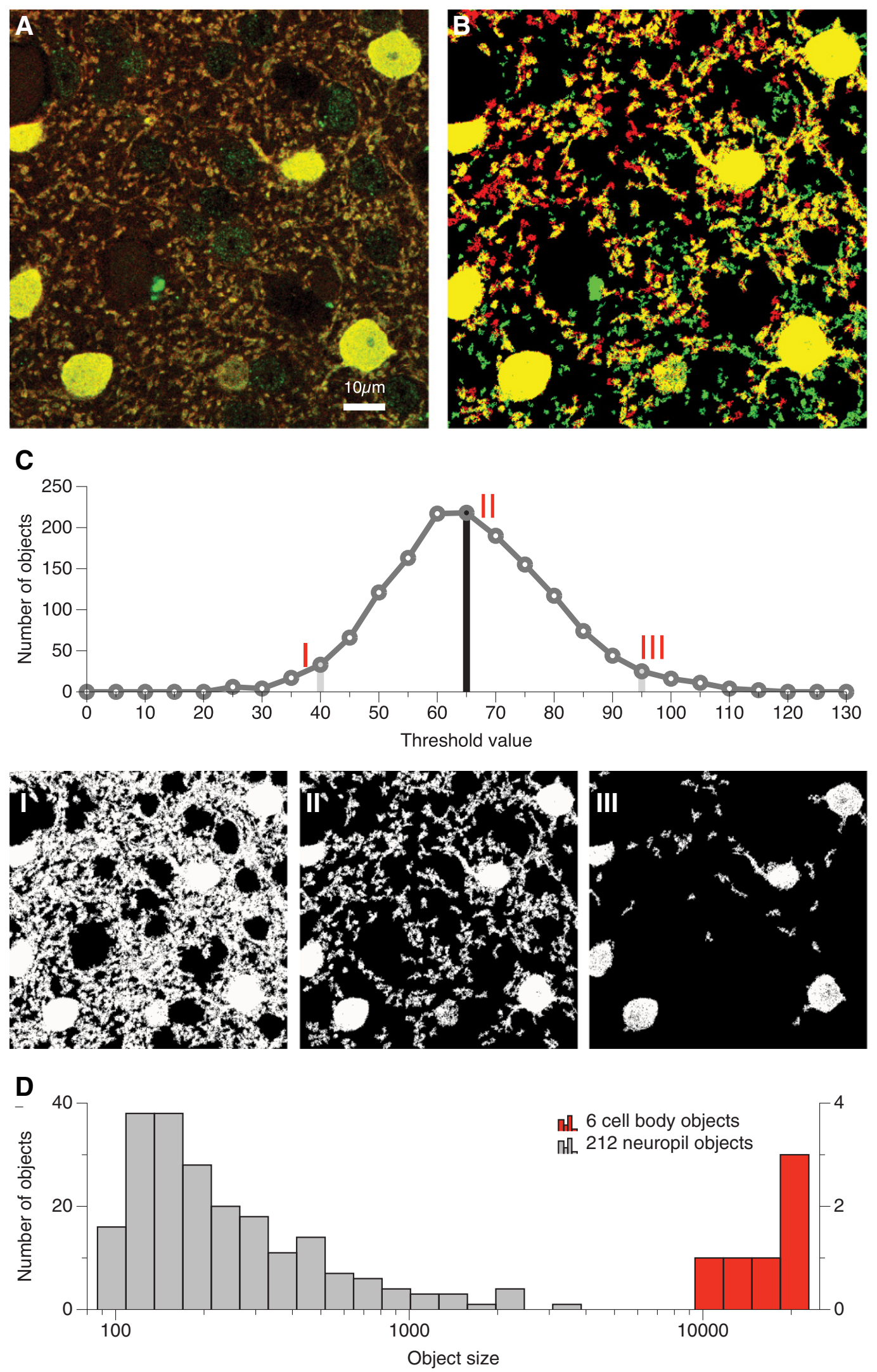

Figure 2. Objective thresholding for the detection of immunoreactive objects. $A$, Stack projection of 10 raw confocal laser scanning microscopy $97 \times 97 \mu \mathrm{m}$ images from a PV (red) and GluA2 (green) double stain in layer IV of macaque V1. B, Projection of the same image stack after automatic thresholding for size and intensity (see Materials and Methods). C, The number of individual, unconnected objects ( $>100$ voxels) in the red (PV) channel, as a function of luminance threshold. I, A low threshold results in the detection of a few contorted objects. II, The optimal threshold leads to the detection of many well defined objects surrounded by empty space. III, A high threshold results in the detection of a few small objects. $\boldsymbol{D}$, Distribution of object sizes of all objects exceeding the size threshold (100 voxels) in the red (PV) channel. Note the logarithmic $x$-axis and the bimodal distribution with a small second peak of very large objects, which correspond to the cell bodies. 
sections on a sliding freezing microtome. We stored the sections for a few weeks at $-20^{\circ} \mathrm{C}$ in $50 \%$ glycerol in buffer. We subsequently stained them as free-floating sections.

We performed systematic random sampling of the successive sections by arranging them from medial to lateral and dividing them into four groups with an equal number of sections. For each colocalization condition, we generated a random number smaller than the group size, and selected the corresponding serial sections from all four groups to ensure that every condition covered the same medial to lateral extent of V1.

Immunohistochemistry. We stained for 12 different combinations of antibodies: against the four AMPAR subunits costained with three antibodies against three CBPs (PV, CB, and CR). Every combination was repeated on the four sections (selected as explained above) per monkey (A and R). We thus analyzed a total of 96 sections, 48 per monkey.

We removed the sucrose and glycerol protection with four rinses in $100 \mathrm{~mm}$ PBS, pH 7.6, and blocked unspecific reactivity with donkey serum in PBS (2:100; 017-000-121, Jackson ImmunoResearch) with NaN3 (1:10,000; 26628-22-8, Sigma-Aldrich) and Triton X-100 (1:1000; Sigma-Aldrich) for $2 \mathrm{~h}$ at room temperature. We subsequently incubated the sections overnight with normal donkey serum (5:100), NaN3, and Triton X-100 and the primary antibodies. We used antibody 235 (1:2000; Swant) to recognize PV-IR cells, CB 38 (1:2000; Swant) for CB-IR cells, and AB5054 (1:2000; Merck Millipore, Millipore Bioscience Research Reagents) for CR-IR cells (Morrow et al., 2007; Mascagni et al., 2009; Tricoire et al., 2011). For the AMPAR subunits, we used AB1504 (1:100; Merck Millipore, Millipore Bioscience Research Reagents) for GluA1 (Wenthold et al., 1996; Betarbet and Greenamyre, 1999), MAB397 (1: 100; Merck Millipore, Millipore Bioscience Research Reagents) for GluA2 (Kessels et al., 2009; Deng et al., 2010), MAB5416 (1:100; Merck Millipore, Millipore Bioscience Research Reagents) for GluA3 (Montgomery et al., 2009), and 06-308 (1:100; Merck Millipore, Millipore) for GluA4 (Martin et al., 1993; Carder, 1997). All primary antibodies used were raised against amino acid sequences preserved between mouse, macaque, and human (zharv;53The UniProt Consortium, 2010), and have been previously tested for specificity in mouse and have also been used in macaque studies (as cited above).

The following day we incubated the sections with their corresponding fluorescent secondary antibodies for $1 \mathrm{~h}$ at $36^{\circ} \mathrm{C}$. When the two primary antibodies were raised in the same host, the procedure involved two separate overnight incubations with the primary antibodies at room temperature, with the first incubation followed by a daytime incubation with an untagged $\mathrm{F}\left(\mathrm{ab}^{\mathrm{I}}\right)_{2}$ fragment $\operatorname{IgG}(\mathrm{H}+\mathrm{L})$ antibody $(1: 100 ; 315-006-003$, 111-006-003, Jackson ImmunoResearch) against the shared host for $1 \mathrm{~h}$ at $36^{\circ} \mathrm{C}$, so that the targets of the fluorescent secondary antibodies became different (see Table 1 for species' correspondence). We used the AlexaFluor 555 (1:500; A-31570, A-31572, A-21432, Invitrogen) secondary antibody for the various cell stains [see Figs. 4 (PV), 6 (CB), 8 (CR), red channels], and the AlexaFluor 488 (1:500; A-21202, A-21206, Invitrogen) secondary antibody for the receptor subunit stains (see Figs. 4, 6, 8 , green). We mounted the sections on glass slides, coverslipped them with the Vectashield cover medium and preserved them in the dark at $4^{\circ} \mathrm{C}$ before imaging.

To control for unspecific staining, we repeated the entire procedure but omitted the primary antibodies and found no fluorescent staining. To control for cross-species reactivity, we tested primary antibodies raised in different species in all conditions and found the same immunostaining patterns as the ones included in the study. These other primary antibodies were excluded from the study due to lack of documented monkey reactivity, despite being raised against similar amino acid sequences. To test the efficiency of the untagged $\mathrm{F}\left(\mathrm{ab}^{\mathrm{I}}\right)_{2}$ in separating the signal of the same-host primary antibodies, we performed the staining procedures, including the $\mathrm{F}\left(\mathrm{ab}^{\mathrm{I}}\right)_{2}$ incubation, and then stained with a fluorescent antibody against the host of the primary antibody; we found no fluorescent signal. The efficiency of this procedure can be seen, for example, in the lack of overlap between the CB and the CR stain (both rabbit primary antibodies) in Figure 1.

To validate the specificity of the antibodies, we performed absorption controls, preincubating the primary antibodies overnight at $4^{\circ} \mathrm{C}$ with the corresponding control peptide (Table 1), at 10:1 peptide-to-antibody
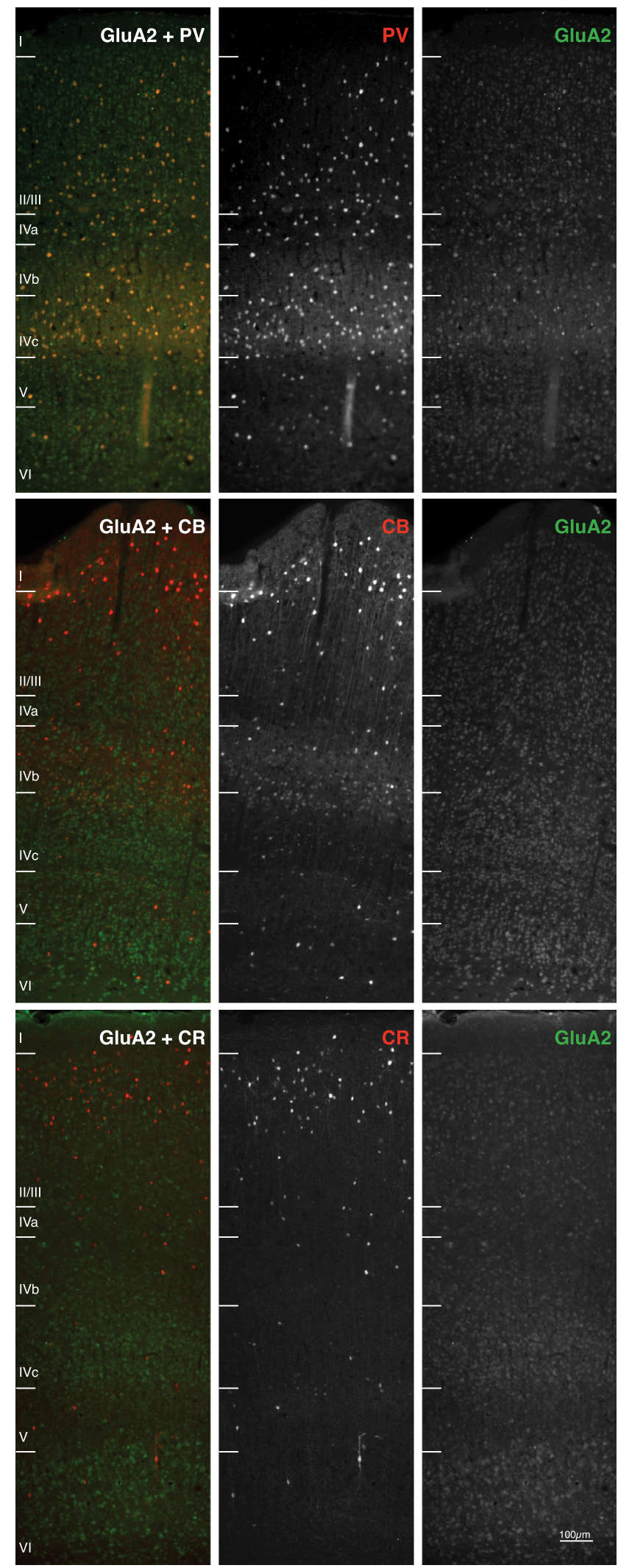

Figure 3. Laminar profile of GluA2 (green) costained with $\mathrm{PV}, \mathrm{CB}$, and $\mathrm{CR}$ (red) in macaque V1. There are different coexpression patterns of GluA2 with the three classes of inhibitory interneurons: high colocalization for $P V$ (yellow double-stained cells present in all layers) and low for $C B$ and $C R$. Note that $C B$-intense and $C R-I R$ cells show no costaining, indicating a lack of GluA2 expression in all layers (left, red-only cells). Also note the presence of a CB-weak population of neurons in intermediate layers that are thought to be excitatory and that express GluA2 (middle left, weak yellow labeling). 

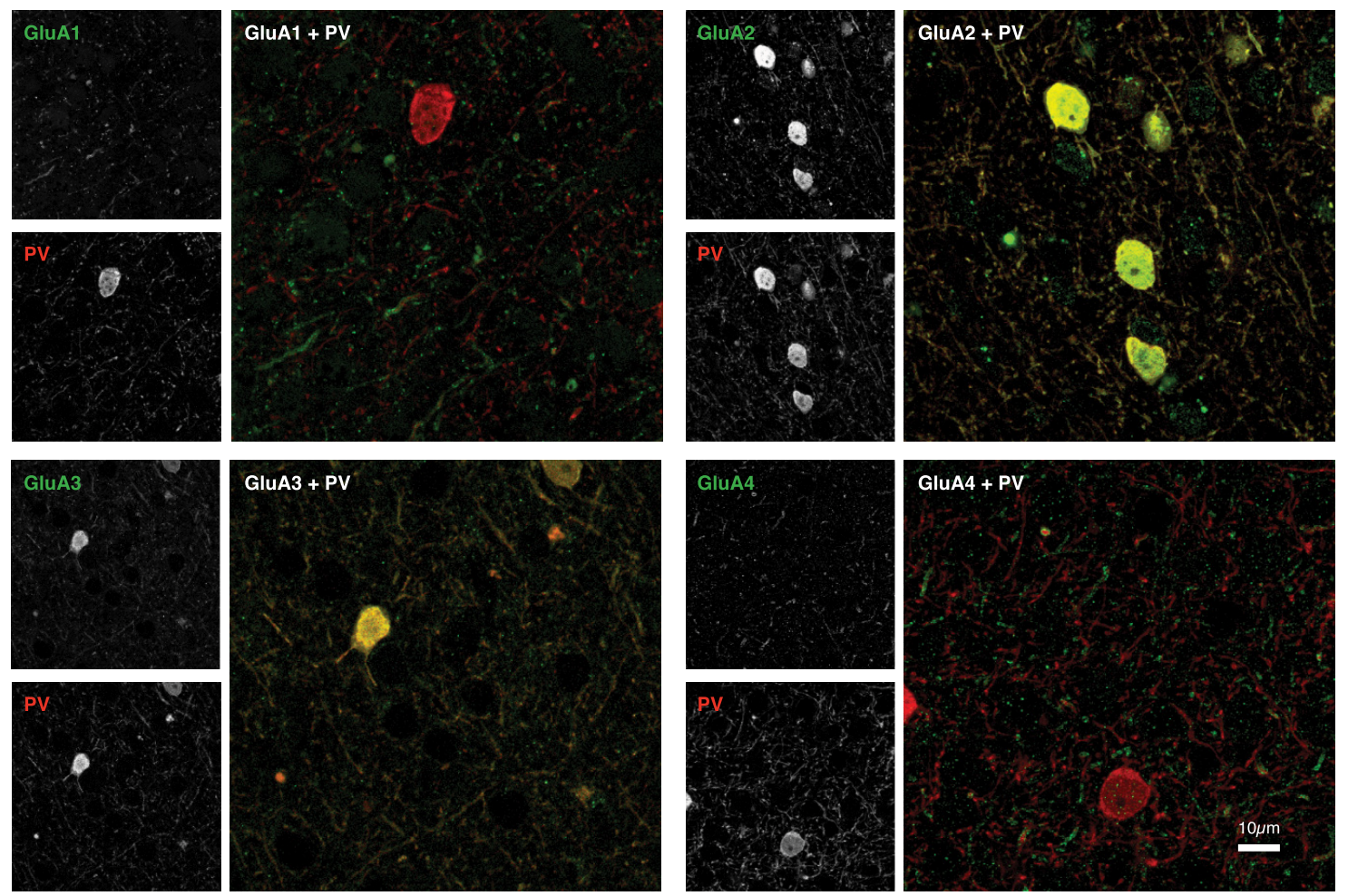

Figure 4. Example double stains $(97 \times 97 \mu \mathrm{m})$ for PV (red) and the four AMPAR subunits (green) in layer II/III, where cell bodies positive for all three CBPs are found. Each image is a stack projection of 10 confocal laser scanning microscopy images. There is little colocalization (yellow) between PV and GluA1 or GluA4 and more overlap between PV and GluA2 or GluA3. Grayscale insets on the left show individual channels.

molar concentration, before performing the procedure described above, and did not observe fluorescent staining.

Imaging and image processing. In every section, we confocally scanned five $z$-stack samples from the same cortical column corresponding to layers I, II/III, IV, V, and VI, as identified by relative cortical depth and cell morphologies (Van Brederode et al., 1990; DeFelipe, 1997; Defelipe et al., 1999; Disney and Aoki, 2008; see Fig. 1 for CBP expression across the layers). We acquired $z$-stacks consisting of 10 successive equidistant images in the $z$ dimension, with two channels, red corresponding to CBPs, and green to AMPARs. We used a Zeiss CLSM 510 and the $63 \times$ immersion objective (numerical aperture, 1.5 ) with $1.5 \times$ digital zoom, at $512 \times 512$ resolution and 8 -bit image depth. We configured the two channels as follows: an AlexaFluor 488 "green" channel (488 nm laser excitation, 500-550 nm emission filtering) and an AlexaFluor 555 "red" channel (543 nm laser excitation, 565-655 nm emission filtering). These settings enabled appropriate sampling and deconvolution of the objects of interest. All multifluorescence scanning was done in sequential, "frame-by-frame" mode. Because of the high colocalization previously documented, e.g., between CB and GluA3 (Moga et al., 2003), we took precautions to rule out emission (green emission in the red channel) and excitation bleed-through (red emission in the green channel). To eliminate the possibility of emission bleed-through, we used band-filtering and sequential scanning (Beliën and Wouterlood, 2012). To exclude the possibility of excitation bleed-through signals (in the green channel), we included single-stained sections before and after each scanning session and tuned the laser and detector settings so that there was no signal in the inappropriate channel. We used these laser and detector settings consistently in all our image acquisition sessions.

In a few stacks, we discarded images of layer I because there were superficial tears in the tissue, which had been caused by the removal of the brain from the skull, but we included the rest of the column in the data analysis.

We deconvolved the image stacks using the Huygens Professional software (Scientific Volume Imaging). This processing step uses the intrinsic point-spread function (PSF) of the optic equipment to reliably recon- struct the original image, thereby improving the estimation of the size and relative position of imaged objects (Wouterlood, 2005; Wouterlood et al., 2008; Boulland et al., 2009). The PSF is proportional to emission wavelength and is therefore different between the two confocal channels.

We used a recently established automated method that is based on 3D object recognition in image stacks, which results in an objective and highly reproducible estimation of the thresholds necessary for 3D object reconstruction that correlates well with manual, subjective procedures (Wouterlood et al., 2008; Beliën and Wouterlood, 2012). To calculate the probability of expression of receptors, we first split every image into 3D objects, where each 3D object consists of a number of connected voxels $(0.19 \times 0.19 \times 0.2 \mu \mathrm{m})$ above a variable luminance threshold. We automatically counted the number of $3 \mathrm{D}$ objects as a function of a luminance threshold, using the ImageJ software together with the "3D object counter" plug-in (Bolte and Cordelières, 2006). To suppress image noise, we excluded from the count objects with 100 connected voxels for the CBP stains and 10 connected voxels for the AMPAR stains. The number of remaining objects counted in this manner is a unimodal function of the threshold (Fig. 2C). Low thresholds detect a few irregular but large 3D objects (Fig. 2C, I), whereas high thresholds result in sparse, small objects with high luminance (Fig. 2C, III; Wouterlood et al., 2008; Beliën and Wouterlood, 2012). The threshold that maximizes the count (Fig. 2C, II) is an intermediate value, and the resulting objects tend to have an intermediate size and their centers of mass are inside the objects. We performed this threshold determination independently for the two channels in each $z$-stack image of the different costaining conditions (Wouterlood et al., 2008; Beliën and Wouterlood, 2012). The distribution of object sizes is bimodal (Fig. 2D). The larger objects represent cell bodies and the smaller objects represent the neuropil. We exploited this size difference to separately analyze the degree of expression of AMPAR subunits on CBP-IR cell bodies and neuropil.

We used scripts processed by the SCIL-Image software (TNO) to calculate the number of the objects in each channel overlapping with objects in the other channel in every stack, taking into consideration their size, 


\section{Probability of GluA expression for PV-IR cells}
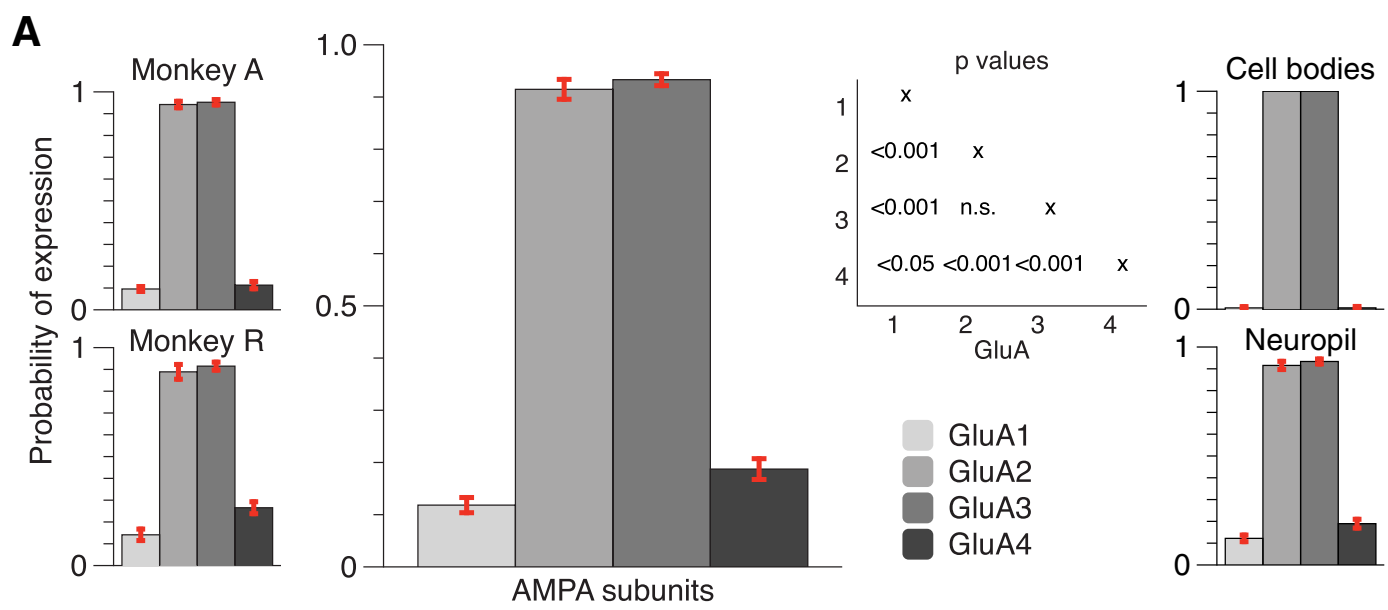

\section{B}

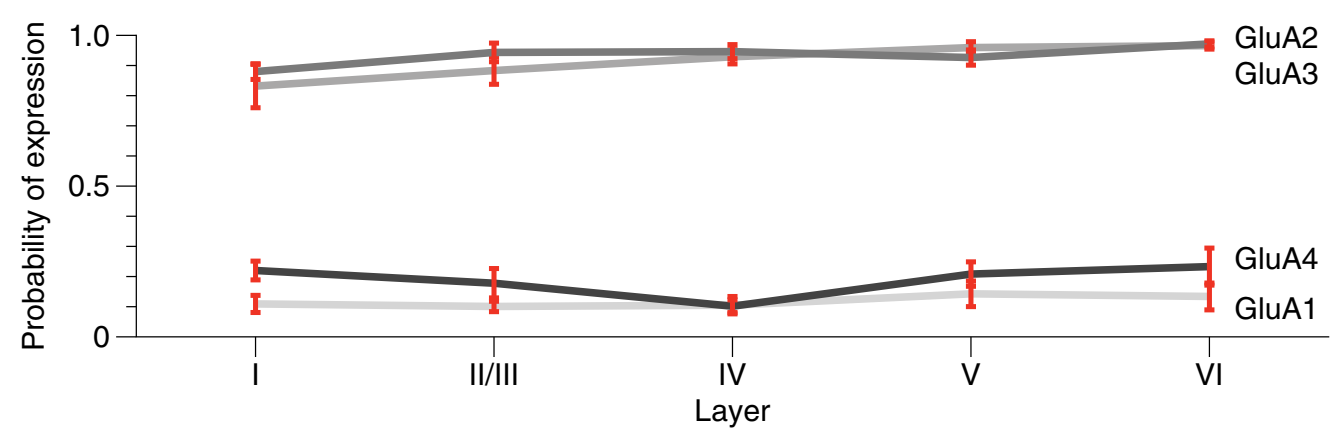

Figure 5. Expression of AMPAR subunits in PV-IR interneurons. A, Average probability across all layers computed from $\sim 40$ images ( 2 monkeys $\times 5$ layer locations $\times 4$ sagittal positions) per bar. Inset on the right shows $p$ values of pairwise comparisons between the four AMPAR subunit expression probabilities. PV-IR cells have a high probability of expressing subunits GluA2 and GluA3, and a lower probability of expressing subunits GluA1 and GluA4. Insets on the left show results of the individual monkeys. Insets on the right show expression in cell bodies and neuropil separately. $\boldsymbol{B}$, Breakdown by layer ( $\sim 8$ samples per data point) reveals that there is little variability across the layers. Error bars represent SEM.

the coordinates of their centers of mass, and the number of overlapping voxels (Wouterlood et al., 2008; Beliën and Wouterlood, 2012).

To characterize the receptor expression patterns of the various cell types, we calculated the fraction of 3D CBP objects (which included both cell bodies and neuropil) overlapping with 3D GluA objects. This fraction is expressed in the following equation:

$$
P(G l u A \mid C B P)=\frac{N_{C B P \text { overlap GluA }}}{N_{C B P}}
$$

The quantity $P(G l u A \mid C B P)$ is the probability that an object positive for a given CBP expresses a given GluA. The quantitative results obtained with $P(G l u A \mid C B P)$ were always in accordance with our qualitative assessment of colocalization when inspecting the images visually.

\section{Results}

The distribution of cell bodies positive for PV, CB, and CR across the cortical layers was similar to that found in previous studies in macaque V1 (Disney and Aoki, 2008; Figs. 1, 3). We found that cell bodies were positive for maximally a single CBP, as has been described previously (Van Brederode et al., 1990; Condé et al., 1994; DeFelipe, 1997; Zaitsev et al., 2005; Disney and Aoki, 2008). Interneurons that are positive for CBPs have specific morphologies (Van Brederode et al., 1990; Condé et al., 1994; Disney and Aoki, 2008) and the laminar distribution of CBP-IR cell bodies observed by us was also in accordance with the laminar position of these morphologies described in previous work (Jones, 1984; Kisvarday et al., 1986; Lund, 1987; Lund et al., 1988; Lund and
Yoshioka, 1991; Lund and Wu, 1997). We found that interneurons express all AMPAR subunits. CBPs colocalized with one of two distinct AMPA subunit profiles: high GluA2 and GluA3 expression (with low GluA1 and GluA4 expression) for PV-IR cells, or high GluA1 and GluA4 expression (with low GluA2 and GluA3 expression) for CB-IR and CR-IR cells. The expression pattern of the AMPA subunits on inhibitory interneurons is similar across the layers (Fig. 3, coexpression of GluA2 with the three CBPs).

\section{PV-IR cells}

PV-IR cell bodies were located in all layers, with distinctive bands of higher cell densities in layers II/III, IVc, and VI (Figs. 1, 3), as is expected for chandelier cells and basket cells, known to express PV (Van Brederode et al., 1990; Condé et al., 1994; Burkhalter, 2008; Disney and Aoki, 2008). We investigated the expression of AMPAR (GluA1 through GluA4) subunits by PV-IR cells (Fig. 4). Our analysis was based on 157 of 160 (two monkeys $\times$ four receptors $\times$ four sagittal locations $\times$ five layer locations) stacks, and three stacks with damage to layer I were removed (see Materials and Methods). We first examined whether there were differences in the density (proportion of voxels above the threshold) of the PV stain between the different colocalization conditions (GluA1 through GluA4), but found that PV density was similar (one-way ANOVA, $F_{(3,153)}=1.322, p>0.25$ ), so that normalizations were unnecessary. 

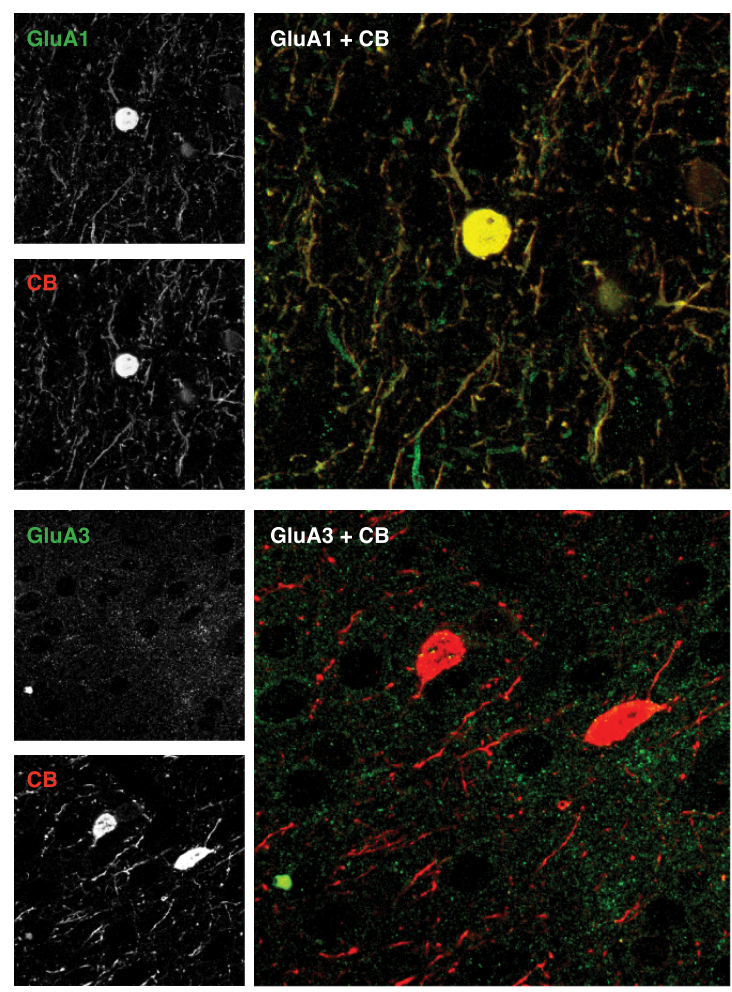
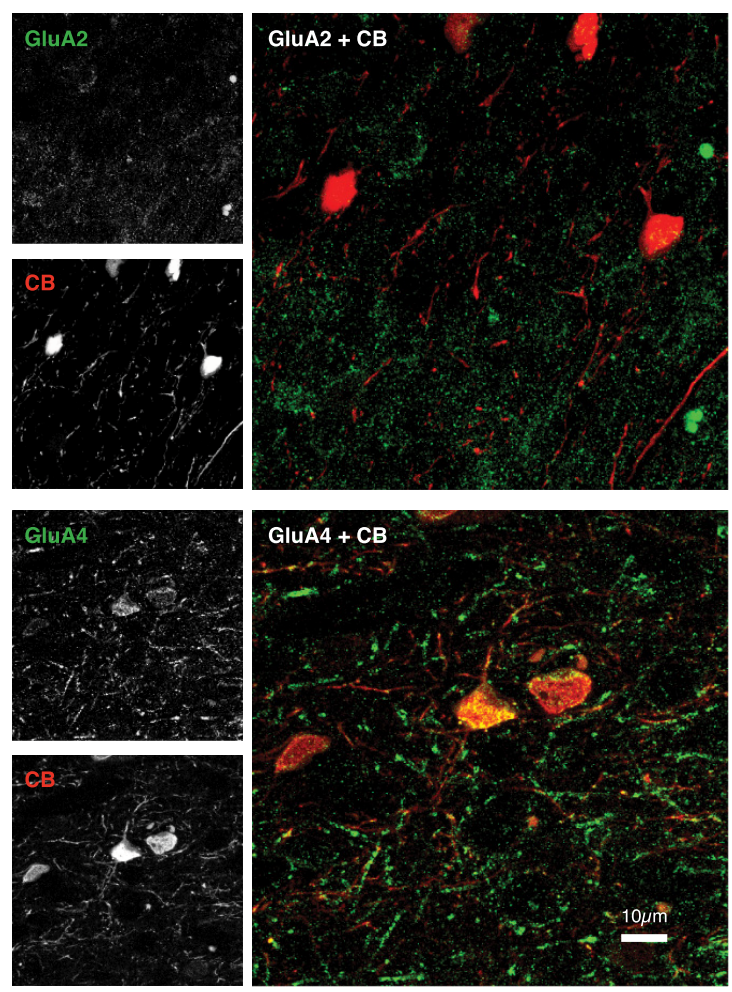

Figure 6. Example double stains $(97 \times 97 \mu \mathrm{m})$ in layer II/III for CB (red) and the AMPAR subunits (green). Each panel shows 10 superimposed confocal laser scanning microscopy images from the same stack. There is strong colocalization (yellow) between CB on the one hand and GluA1 and GluA4 on the other. There is little overlap between CB and GluA2 or GluA3. Grayscale insets depict the individual channels.

We observed a remarkable specificity in the colocalization of PV with GluA1 through GluA4. PV-IR cells exhibited strong expression of GluA2 and GluA3 (Figs. 2-4, yellow objects) and much weaker expression of GluA1 and GluA4 (Figs. 3, 4, separate green and red objects). In our main analysis, we included neuropil and cell bodies as PV-expressing "objects." Across all layers, the probability $P(G l u A 2 \mid P V)$ that a PV-positive object expressed GluA2 was on average $0.91(N=39)$ and the mean $P(G l u A 3 \mid P V)$ was $0.93(N=39$; Fig. 5$)$. In contrast, the probability of expression was much lower for the other AMPAR subunits with an average $P(G l u A 1 \mid P V)$ of $0.12(N=40)$ and $P(G l u A 4 \mid P V)$ of 0.19 $(N=39)$. To test the significance of these differences in colocalization, we performed a two-way ANOVA, with layer and GluA subunit as factors. We observed a significant main effect of GluA subunit $\left(F_{(3,137)}=755.331, p<0.001\right)$. A post hoc analysis revealed no significant difference between the high GluA2 and GluA3 expression levels (Bonferroni-corrected $t$ test, $p>0.9$ ). However, the differences between the high values of $P(G l u A 2 \mid P V)$ and $P(G l u A 3 \mid P V)$, on the one hand, and lower values of $P(G l u A 1 \mid P V)$ and $P(G l u A 4 \mid P V)$, on the other, were all significant (all four Bonferroni-corrected $t$ tests, $p<0.001$ ). Moreover, $P(G l u A 1 \mid P V)$ was significantly lower than $P(G l u A 4 \mid P V)$ (Bonferronicorrected $t$ test, $p<0.05)$. The ANOVA did not reveal a main effect of layer $\left(F_{(4,137)}=2.386, p>0.05\right)$ and there was also no significant interaction between the layer and AMPAR subunit $\left(F_{(12,137)}=1.076, p>0.3\right.$; Fig. $\left.5 B\right)$. Furthermore, the expression of the AMPAR subunits by PV-IR cells was similar in the two monkeys (Fig. 5A, left insets). The patterns of expression were similar when we analyzed the neuropil (i.e., the smaller objects, which formed the majority) expressing PV separately (Fig. 5A, right upper inset). However, the specificity of the expression patterns became virtually absolute when we included cell bodies only (i.e., the few larger objects) in our analysis (Fig. 5A, right lower inset).

These results demonstrate that PV-IR cells strongly express the GluA2 and GluA3 AMPAR subunits and have a much lower expression of GluA1 and GluA4 subunits, which are almost entirely lacking from cell bodies. This expression pattern is homogenous across all layers of macaque V1.

\section{CB-IR cells}

CB-IR-positive cell bodies were mostly located in layers II/III and IV (Figs. 1, 3). We focused our analysis on the CB-intense population, which is inhibitory (Van Brederode et al., 1990; Disney and Aoki, 2008). The morphologies of these cells resembled Martinotti and neurogliaform cells, as previously described (Jones, 1984; Van Brederode et al., 1990; Condé et al., 1994; Burkhalter, 2008). We also observed a weak band of neurons that exhibited a low level of CB expression in the intermediate layers. These cells are thought to be excitatory (Van Brederode et al., 1990) and, accordingly, they did express the GluA2 subunit (Wenthold et al., 1996; Leuschner and Hoch, 1999; Ayalon and Stern-Bach, 2001; Kessels and Malinow, 2009). However, these excitatory neurons did not reach the threshold of 100 connected voxels for the detection of CBP-positive objects (see Materials and Methods) due to their low level of $\mathrm{CB}$ expression and they did not contribute to the measured degree colocalization (Fig. 3).

We examined the density of the CB-IR staining across the costaining conditions with the four GluA subunits (Fig. 6) but did not observe significant differences between stains (one-way ANOVA, $\left.F_{(3,155)}=0.161, p>0.9\right)$ so that normalization was unnecessary. We performed the same analysis steps as described above for the PV-IR cells for 159 image stacks. A two-factor ANOVA (GluA $\times$ layer) revealed a significant main effect of 


\section{Probability of GluA expression for CB-IR cells}
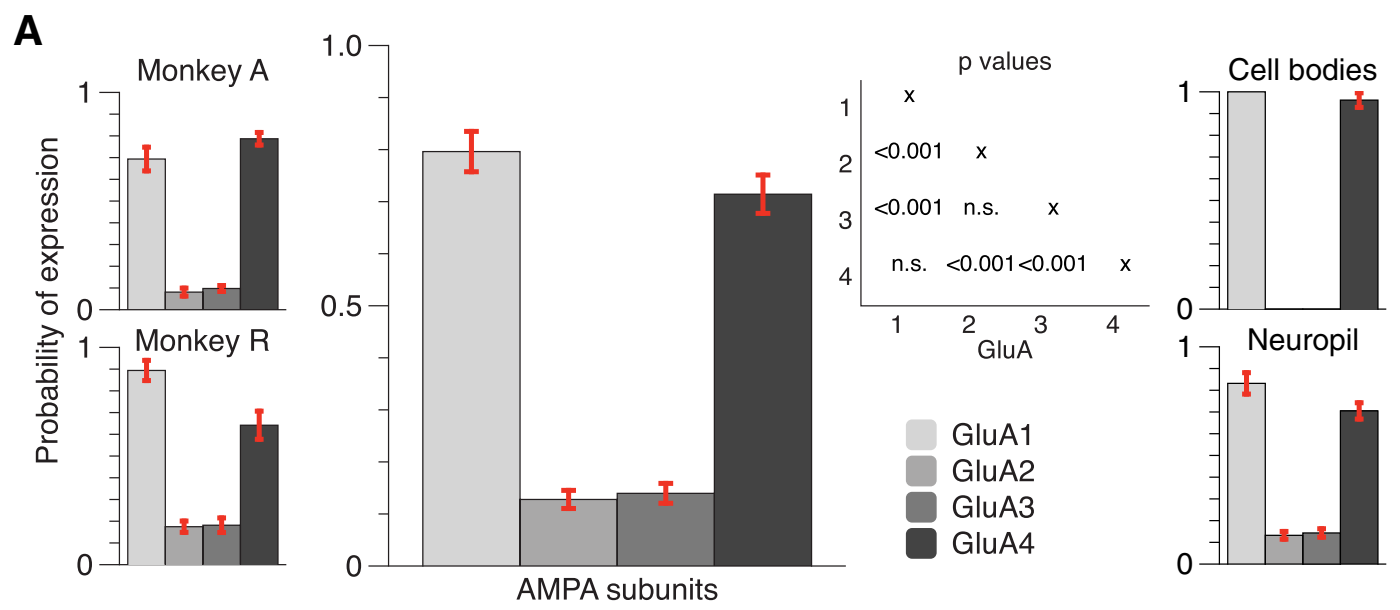

B

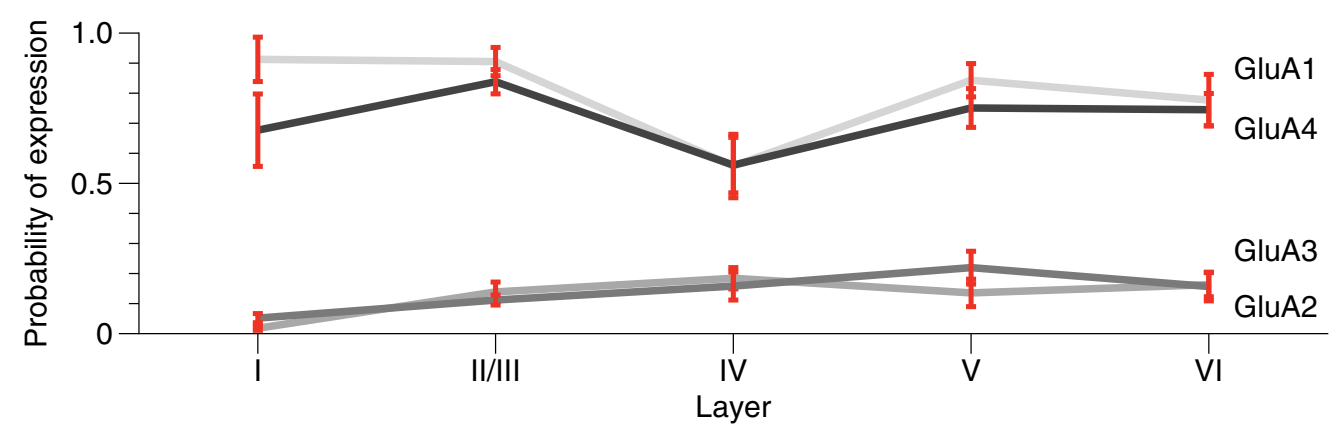

Figure 7. Expression of AMPAR subunits in CB-IR interneurons. A, Average probability across all layers computed from $\sim 40$ samples per bar. CB-IR cells have a low probability of expressing GluA2 and GluA3, and a high probability of expressing GluA1 and GluA4. Insets on the left show the results of the individual monkeys. Insets on the right show expression for cell bodies and neuropil separately. B, Breakdown by layer (8 samples per data point) reveals little layer variability in the expression of GluA2 and GluA3 but lower expression of GluA1 and GluA4 in layer IV. Error bars represent SEM.

GluA subunit on expression $\left(F_{(3,139)}=174.617, p<0.001\right)$, a significant main effect of layer $\left(F_{(4,139)}=3.272, p<0.05\right)$, and a significant interaction between these factors $\left(F_{(12,139)}=2.434\right.$, $p<0.01$; Fig. 7A). The GluA main effect was driven by an increased expression of GluA1 and GluA4 by CB-IR cells, compared with GluA2 and GluA3. The mean $P(G l u A 1 \mid C B)$ was 0.80 $(N=39)$ and the mean $P(G l u A 4 \mid C B)$ was $0.71(N=40)$, whereas $P(G l u A 2 \mid C B)(N=40)$ and $P(G l u A 3 \mid C B)(N=40)$ equaled 0.13 and 0.14 , respectively. We observed no significant differences between the degrees of expression of GluA1 and GluA4 or between GluA2 and GluA3 receptor subunits (Bonferronicorrected $t$ tests, both $p$ 's $>0.2$ ). However, the pairwise comparisons between the more strongly and more weakly expressed subunits were all highly significant (GluA1 or GluA4 vs GluA2 or GluA3; all p's $<0.001)$. We confirmed these results when analyzing the data of the two monkeys separately (Fig. 7A, left insets). The degree of expression in the neuropil was similar to that when we pooled across objects of all sizes. However, the specificity of the expression pattern was virtually absolute when we analyzed the cell bodies (Fig. 7A, right insets). The main effect of layer on the probability of expression and the interaction with GluA was mainly driven by a lower expression of the GluA1 subunit in layer IV. There was a significant difference in expression of the GluA1 subunit between layers II/III and IV ( $t$ test with Bonferroni correction, $p<0.05)$, and a trend in the same direction when comparing layer IV to V $(p=0.053$; Fig. $7 B)$.
Thus, the GluA subunit expression pattern for CB-IR cells is opposite that of PV-IR cells. CB-IR cells strongly express GluA1 and GluA4, but have a lower expression of GluA2 and GluA3 in the neuropil, and GluA2 and GluA3 are virtually absent from cell bodies. The laminar pattern of GluA expression was not entirely homogenous, with a slightly lower expression of GluA1 in layer IV.

\section{CR-IR cells}

CR-positive cell bodies were mainly located in layer II/III (Figs. 1, 3 ), but their processes extended throughout the entire cortical column. The morphology of the CR-IR cells was compatible with the morphology that was previously described for double bouquet cells (Condé et al., 1994; Burkhalter, 2008). The cell-staining density was similar across the AMPA subunit costaining conditions $\left(F_{(3,155)}=0.80, p>0.9\right)$.

Figure 8 illustrates the colocalization between CR and the four AMPAR subunits. We observed that CR-IR cells strongly expressed GluA1 and GluA4, while expression of GluA2 and GluA3 was weaker. We again used a two-way ANOVA to assess the reliability of these effects across 159 slices (Fig. 9). We observed a significant main effect of GluA subunit $\left(F_{(3,139)}=295.954, p<\right.$ $0.001)$. The expression of GluA1 on CR-IR cells was strong [average $P(G l u A 1 \mid C R), 0.9 ; N=39$ ], expression of GluA4 was slightly weaker $[P(G l u A 4 \mid C R)=0.57, N=39]$, and expression of GluA2 and GluA3 was much weaker $(P($ GluA2 $\mid C R)=0.17$ and 

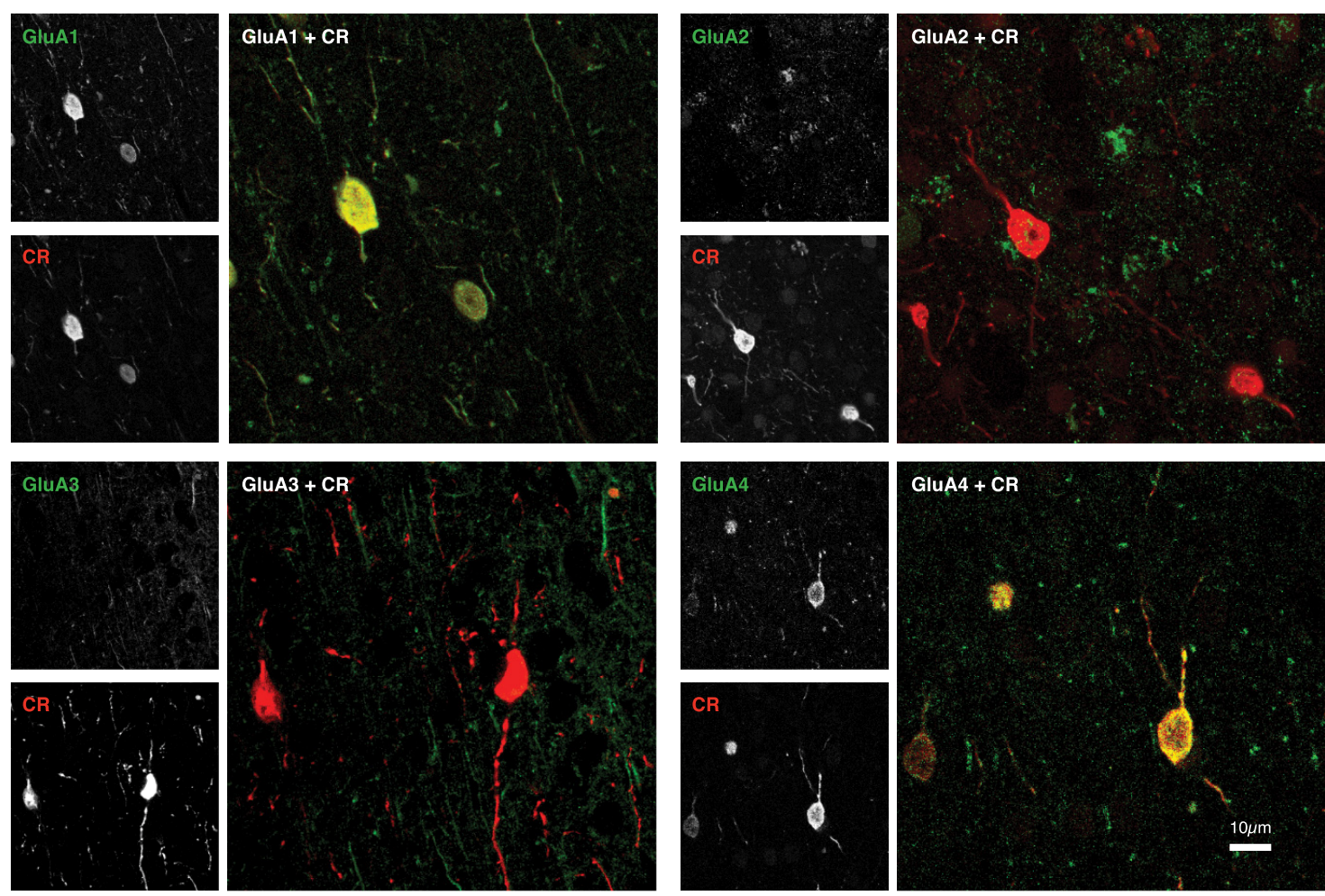

Figure 8. Example double stains $(97 \times 97 \mu \mathrm{m})$ in layer II/III for calretinin (red) and the AMPAR subunits (green). Images show a superimposition of 10 confocal laser scanning microscopy images from the same stack. There is colocalization (yellow) between CR on the one hand and GluA1 and GluA4 on the other. Colocalization between CR and GluA2 or GluA3 is weak. Grayscale insets on the left represent image channels.

$P(G l u A 3 \mid C R)=0.17)$. The difference in CR expression of GluA1 and GluA4 by CR-IR cells was significant $(p<0.001)$, and the differences between GluA1 and GluA4 on the one hand and GluA2 and GluA3 on the other were all significant $(p<0.001)$ as well. We did not observe a significant main effect of layer $\left(F_{(4,139)}\right.$ $=0.630, p>0.6)$ and also no GluA $\times$ layer interaction $\left(F_{(12,139)}\right.$ $=0.734, p>0.7)$. Again, the results also held up when analyzing the data of the two monkeys separately (Fig. 9A, left insets). Furthermore, the colocalization between AMPARs and CR in the neuropil was similar to that when we pooled across objects of all sizes, whereas the specificity of colocalization was much more pronounced when we analyzed the cell bodies separately, with very low levels of expression of the GluA2 and GluA3 subunits (Fig. 9A, right insets)

Thus, the expression pattern of GluA subunits for CR-IR cells was similar to that of CB-IR cells. CR-IR cells are likely to express GluA1 and GluA4, but less likely to express GluA2 and GluA3. The AMPAR subunit expression pattern was similar across the cortical layers, which is presumably caused by a relatively homogenous cell population with cell bodies in layer II/III and processes spanning the entire cortical depth (Figs. 1, 3).

\section{Discussion}

Recent studies have started to reveal different functions of the various classes of interneurons (Isaacson and Scanziani, 2011; Adesnik et al., 2012). There are a number of classification schemes for inhibitory interneurons (Burkhalter, 2008), and in macaque visual cortex they can be distinguished on the basis of CBPs, which divide them into nonoverlapping populations (Condé et al., 1994; Disney and Aoki, 2008). PV-IR cells are chandelier and basket cells, CB-IR cells are Martinotti and neurogliaform cells, and CR-IRs cells are predominantly double bouquet cells (Condé et al., 1994). The present data reveal a remarkably specific AMPAR-subunit expression in these inhibitory interneuron classes in area V1. PV-neurons express high levels of the GluA2 and GluA3 subunits and low levels of the GluA1 and GluA4 subunits. The GluA expression of $\mathrm{CR}$ and $\mathrm{CB}$ cells is reversed, with high concentrations of GluA1 and GluA4, combined with low levels of GluA2 and GluA3.

It is of interest to compare our results to those of a previous study (He et al., 2001) showing that $\sim 90 \%$ of GABAergic cells in layer II/III express the GluA2 subunit. We found that GluA2 expression is particularly high in PV-IR cells, but in layer II/III these PV cells are accompanied by a substantial fraction of CB-IR and CR-IR cells with a low expression of the GluA2 subunit. Differences in methodology (anti-GABA antibody sensitivity) and quantification procedures may have caused this discrepancy.

Furthermore, Hull et al. (2009) demonstrated that thalamocortical input to PV-IR cells in mouse barrel cortex activates GluA2-lacking AMPARs. We do not know whether this difference between results is specific to the thalamocortical projections or caused by a difference between mouse and monkey. At the same time, the low concentration of GluA2 in CB-IR and CR-IR cells observed by us is in accordance with a study in the visual cortex of the hamster (Ryoo et al., 2003) where GluA2-positive cells were found to be virtually devoid of $\mathrm{CB}$ and CR.

An important topic for future studies will be to systematically compare the expression of AMPAR subunits across species. The same holds true for the comparison between brain structures, such as cortex and hippocampus (Chang et al., 2010).

At the same time, our findings go beyond those of earlier studies by characterizing the expression profile of all AMPAR subunits in PV-positive, CB-positive, and CR-positive cells in the 


\section{Probability of GluA expression for CR-IR cells}

A
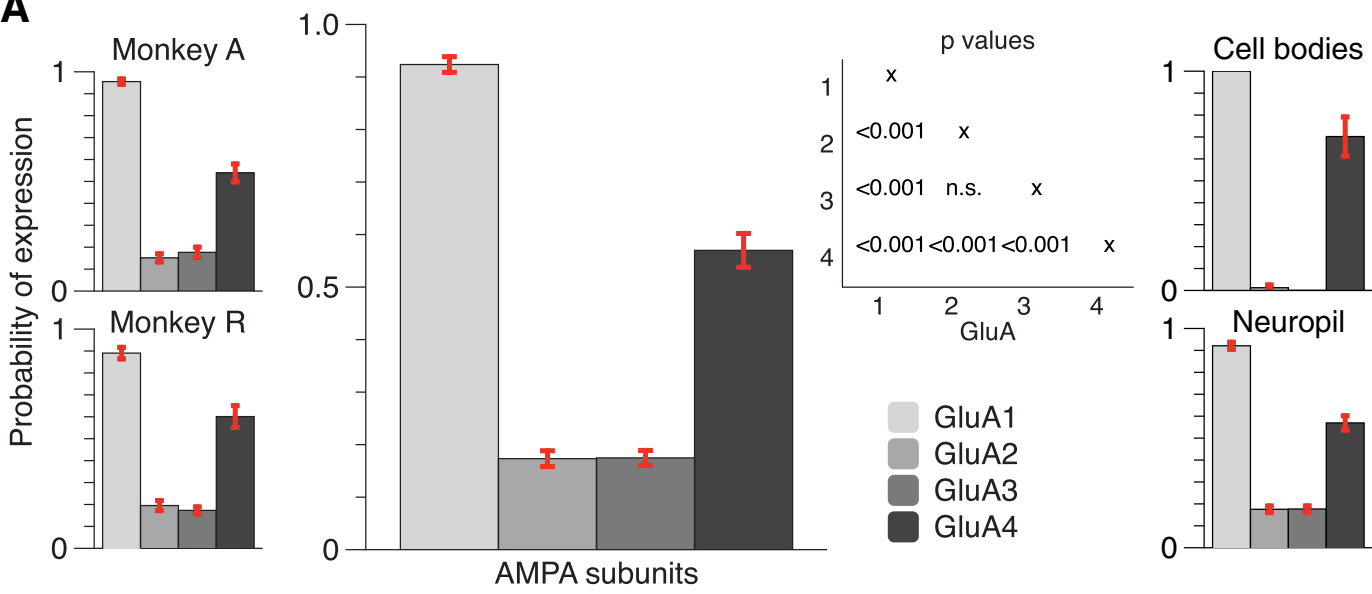

B

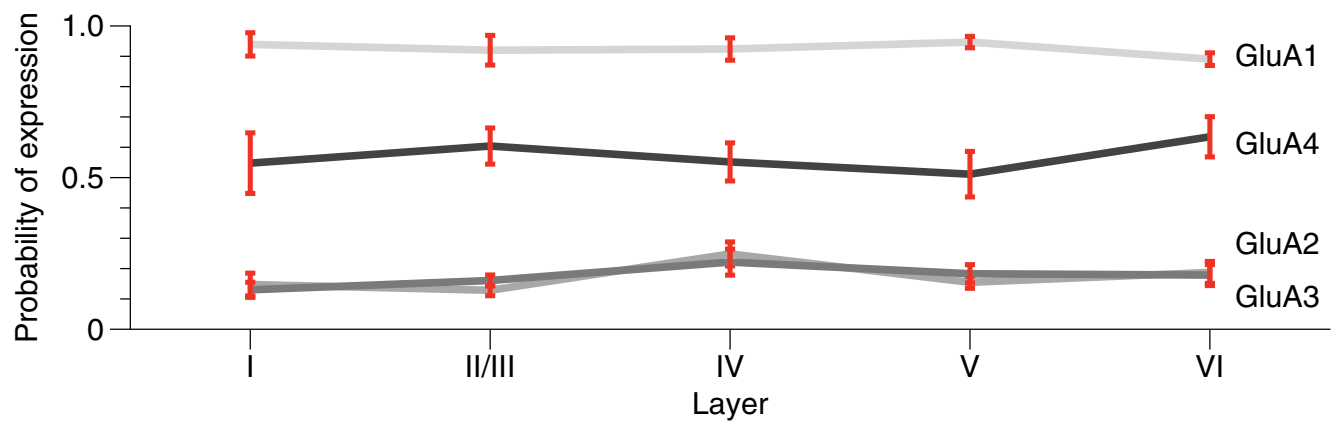

Figure 9. Expression of AMPAR subunits in CR-IR interneurons. A, Average probability across the layers, computed from $\sim 40$ samples ( 2 specimens $\times 5$ layer locations $\times 4$ sagittal positions) per bar. CR-IR cells have a low expression of GluA2 and GluA3, and a higher expression of GluA1 and GluA4. Insets on the left show individual monkey results. Insets on the right show expression in cell bodies and neuropil separately. $\boldsymbol{B}$, Breakdown by layers ( 8 samples per each data point) reveals that the results are homogeneous across the layers. Error bars represent SEM.

Table 2. Overview of correspondence between interneuron morphology, CBPs, firing pattern, and AMPAR subunit expression

\begin{tabular}{|c|c|c|c|}
\hline$\overline{\mathrm{CBP}}$ & Morphology & Physiology & AMPARs \\
\hline \multirow[t]{2}{*}{ PV } & Chandelier cells (Van Brederode et al., 1990; Condé et al., 1994; Burkhalter, 2008) & Fast spiking (Zaitsev et al., 2005; Burkhalter, 2008) & $\begin{array}{l}\text { GluA1: low } \\
\text { GluA2: high }\end{array}$ \\
\hline & Basket cells (Van Brederode et al., 1990; Condé et al., 1994; Burkhalter, 2008) & $\begin{array}{l}\text { Fast spiking (Zaitsev et al., 2005; Burkhalter, 2008; Povysheva et al., 2008) } \\
\text { GluA4: low }\end{array}$ & GluA3: high \\
\hline \multirow[t]{2}{*}{ CB } & Neurogliaform cells (Jones, 1984; Condé et al., 1994; Burkhalter, 2008) & Intermediate spiking (Zaitsev et al., 2005; Povysheva et al., 2007) & $\begin{array}{l}\text { GluA1: high } \\
\text { GluA2: low }\end{array}$ \\
\hline & Martinotti cells (Van Brederode et al., 1990; Condé et al., 1994; Burkhalter, 2008) & Intermediate spiking (Zaitsev et al., 2005; Burkhalter, 2008) & $\begin{array}{l}\text { GluA3: low } \\
\text { GluA4: high }\end{array}$ \\
\hline CR & Double bouquet (Condé et al., 1994; Burkhalter, 2008) & Intermediate spiking (Zaitsev et al., 2005; Burkhalter, 2008) & $\begin{array}{l}\text { GluA1: high } \\
\text { GluA2: low } \\
\text { GluA3: low } \\
\text { GluA4: high }\end{array}$ \\
\hline
\end{tabular}

macaque monkey. The present results demonstrate for the first time that the AMPAR subunit expression divides the inhibitory interneurons in V1 into two categories, which are congruent with the CBP classification scheme and also with classification methods based on the neurons' firing behavior (Zaitsev et al., 2005). PV-IR cells that show high expression of GluA2 and GluA3 are fast-spiking interneurons, whereas CB-IR and CR-IR cells with high expression of GluA1 and GluA4 are intermediately spiking cells (Table 2). The AMPAR subunit composition may influence the synaptic calcium influx and may also have pharmacological implications, as discussed below.

\section{Methodological issues}

There are a number of possible methodological concerns. A basic premise is the specificity of antibodies and the absence of crossreactivity. Our choice of primary antibodies was based on previous published data (see Materials and Methods) and their specificity is supported by the excellent match with previous descriptions of the laminar profile and morphology of the three inhibitory cell classes (Condé et al., 1994; Disney and Aoki, 2008). We conducted control experiments to rule out cross-reactivity between primary and secondary antibodies (see Materials and Methods). Furthermore, we found that the cell density of the CBP 
stains was similar regardless of the AMPAR subunit stain. Finally, the triple stain for three CBPs that used the same $\mathrm{F}(\mathrm{ab})$ procedure resulted in a clear separation between the three cell classes (Fig. 1), as predicted by previous work (Condé et al., 1994; Disney and Aoki, 2008). In addition, we used a new objective quantitative method to measure colocalization that permits the measurement of the probability that an object positive for one of the CBPs is also positive for one of the GluA subunits (Wouterlood et al., 2008; Beliën and Wouterlood, 2012). Importantly, the results of the quantitative analysis were always in accordance with visual inspection of the data (Figs. 4, 6, 8).

\section{Subunit composition and dimerization}

The AMPAR consists of four subunits, either all identical, or two pairs of different types. In other words, they form either homomeric or heteromeric tetramers (Dingledine et al., 1999; Leuschner and Hoch, 1999; Ayalon and Stern-Bach, 2001). Only a subset of all possible GluA subunit combinations is present in vivo (Wenthold et al., 1996; Greger et al., 2002). Configurations of AMPARs with the GluA1/2 and GluA2/3 dimers have been studied extensively because they are abundant in excitatory cells (Wenthold et al., 1996; Leuschner and Hoch, 1999; Ayalon and Stern-Bach, 2001; Kessels and Malinow, 2009). Our data demonstrate that inhibitory interneurons express AMPAR subunits in combinations that are different from those documented in excitatory cells (Wenthold, 1996; Leuschner and Hoch, 1999; Ayalon and Stern-Bach, 2001; Kessels and Malinow, 2009). We find that interneurons preferentially express either GluA2 and GluA3 (PV-IR cells), or GluA1 and GluA4 (CB-IR and CR-IR cells). Although immunohistochemistry does not measure the precise subunit composition of AMPARs, our results combined with previous findings suggest that the expression of GluA2 and GluA3 is in the form of dimeric GluA2/3 receptors. Homomeric tetramers of GluA2 (Greger et al., 2002; Kessels et al., 2009) or GluA3 (Wenthold et al., 1996) have not been reported in vivo. Furthermore, we found that the expression probability of GluA2 expression was similar to the probability of GluA3 expression for each CBP analyzed.

In contrast, GluA1 (Lerma et al., 1994; Wenthold et al., 1996) and GluA4 (Zhu et al., 2000) occur as homomeric tetramers in vivo, whereas GluA1/4 has only been reported in vitro (Leuschner and Hoch, 1999). In accordance with these findings, we found that the expression probabilities of GluA1 and GluA4 subunits varied independently across inhibitory cell types, with more GluA4 than GluA1 in PV-IR neurons, more GluA1 than GluA4 in CR-IR neurons, and similar expression levels in CB-IR neurons.

\section{Synaptic calcium influx}

AMPARs composed of different subunit combinations exhibit distinct ionic conductances (Swanson et al., 1997; Monyer et al., 2000; Boehm and Malinow, 2005; Kim et al., 2006; Kessels and Malinow, 2009). AMPARs containing the GluA2 subunit, which are abundant on PV-IR interneurons, are impermeable for $\mathrm{Ca}^{2+}$ (Lerma et al., 1994; Dingledine et al., 1999). Thus, PV-IR interneurons in area V1 that express GluA2 and GluA3 (most likely as GluA2/3 dimers) presumably have limited calcium inflow through their AMPARs. Using electrophysiology, $\mathrm{Ca}^{2+}$-permeable receptors have been demonstrated in PV-IR cells of the rat (Aponte et al., 2008), which fits with our finding that GluA1 and GluA4 are not completely absent from PV cells. Yet, the $\mathrm{Ca}^{2+}$ influx into other inhibitory cell types, CB-IR and CR-IR, is higher (Helmchen et al., 1996; Koester and Sakmann, 2000; Lee et al., 2000; Kaiser et al., 2001; Aponte et al., 2008), a finding that can be explained by the higher concentrations of $\mathrm{Ca}^{2+}$-permeable AMPARs composed of GluA1 or GluA4. The high concentration of $\mathrm{Ca}^{2+}$ impermeable AMPARs in PV-IR cells may also contribute to their relatively weak signal in calcium imaging experiments (Hofer et al., 2011).

\section{Pharmacology}

The absence of drugs that target individual AMPAR subunits has hampered studies that aim to disentangle their potentially different functions in vivo. Polyamine toxins, which can be isolated from spiders and wasps, are an exception in this respect because they do block non-NMDA ionotropic receptors in a partially selective manner. Recent pharmacological developments have improved the specificity of polyamines synthetically so that they become selective for AMPARs that lack GluA2 (Koike et al., 1997; Strømgaard et al., 2005; Hull et al., 2009). The present results demonstrate that, in macaque V1, these GluA2-lacking AMPARs are primarily expressed by CB-IR and CR-IR cells. Future studies investigating the role of these cells in regulating cortical activity might use these polyamines to selectively block CB-IR and CR-IR cells in vivo, without affecting PV-IR cells expressing GluA2/3 or excitatory neurons that express GluA1/2 and GluA2/3 (DeFelipe, 1997; Defelipe et al., 1999; Adesnik et al., 2012).

\section{Differences between cortical layers}

The coexpression pattern of CBPs and AMPAR subunits was relatively homogenous across the cortical layers. CB-IR cells are the one exception to this homogeneity, expressing high levels of GluA1 and GluA4 in all layers, but somewhat lower levels in layer IV. The CB-IR cells in layer IV of V1 are primarily neurogliaform cells (Jones, 1984; Nieuwenhuys et al., 2007). The presence of neurogliaform cells in layer IV is characteristic of primate V1 (Kisvarday et al., 1986, 1990) and somatosensory cortex (Nieuwenhuys et al., 2007), where a segregated band of CB-IR cell bodies can be visualized in layer IVb (Van Brederode et al., 1990; Pinheiro Botelho et al., 2006). These cells are absent in other cortical areas, such as prefrontal cortex (Condé et al., 1994). We therefore hypothesize that the weaker expression of GluA1 and GluA4 in layer IV is related to the presence of CB-IR neurogliaform cells that may differ slightly from the other CB-IR cell types.

\section{Conclusion}

Table 2 summarizes the present results and their relation to previous work. We conclude that there are two complementary populations of inhibitory interneurons, which match the division identified by Zaitsev et al. (2005), based on firing behavior. PV-IR neurons mainly express GluA2/3 and are fast-spiking cells, whereas CB-IR and CR-IR neurons predominantly express GluA1 and GluA4 and are intermediate spiking. Future studies may take advantage of the new possibilities to target CB-IR and CR-IR cells pharmacologically to further elucidate their role in cortical processing.

\section{References}

Adesnik H, Bruns W, Taniguchi H, Huang ZJ, Scanziani M (2012) A neural circuit for spatial summation in visual cortex. Nature 490:226-231. CrossRef Medline

Aponte Y, Bischofberger J, Jonas P (2008) Efficient Ca2+ buffering in fastspiking basket cells of rat hippocampus. J Physiol 586:2061-2075. CrossRef Medline

Ayalon G, Stern-Bach Y (2001) Functional assembly of AMPA and kainate receptors is mediated by several discrete protein-protein interactions. Neuron 31:103-113. CrossRef Medline

Beliën JAM, Wouterlood FG (2012) Confocal laser scanning: of instrument, 
computer processing and men. In: Cellular imaging techniques for neuroscience and beyond, Ed 1 (Wouterlood FG, ed), pp 1-41. Amsterdam: Elsevier.

Betarbet R, Greenamyre JT (1999) Differential expression of glutamate receptors by the dopaminergic neurons of the primate striatum. Exp Neurol 159:401-408. CrossRef Medline

Boehm J, Malinow R (2005) AMPA receptor phosphorylation during synaptic plasticity. Biochem Soc Trans 33:1354-1356. CrossRef Medline

Bolte S, Cordelières FP (2006) A guided tour into subcellular colocalization analysis in light microscopy. J Microsc 224:213-232. CrossRef Medline

Boulland JL, Jenstad M, Boekel AJ, Wouterlood FG, Edwards RH, StormMathisen J, Chaudhry FA (2009) Vesicular glutamate and GABA transporters sort to distinct sets of vesicles in a population of presynaptic terminals. Cereb Cortex 19:241-248. CrossRef Medline

Burkhalter A (2008) Many specialists for suppressing cortical excitation. Front Neurosci 2:155-167. CrossRef Medline

Carder RK (1997) Immunocytochemical characterization of AMPAselective glutamate receptor subunits: laminar and compartmental distribution in macaque striate cortex. J Neurosci 17:3352-3363. Medline

Carder RK, Hendry SH (1994) Neuronal characterization, compartmental distribution, and activity-dependent regulation of glutamate immunoreactivity in adult monkey striate cortex. J Neurosci 14:242-262. Medline

Chang MC, Park JM, Pelkey KA, Grabenstatter HL, Xu D, Linden DJ, Sutula TP, McBain CJ, Worley PF (2010) Narp regulates homeostatic scaling of excitatory synapses on parvalbumin-expressing interneurons. Nat Neurosci 13:1090-1097. CrossRef Medline

Condé F, Lund JS, Jacobowitz DM, Baimbridge KG, Lewis DA (1994) Local circuit neurons immunoreactive for calretinin, calbindin D-28k or parvalbumin in monkey prefrontal cortex: distribution and morphology. J Comp Neurol 341:95-116. CrossRef Medline

DeFelipe J (1997) Types of neurons, synaptic connections and chemical characteristics of cells immunoreactive for calbindin-D28K, parvalbumin and calretinin in the neocortex. J Chem Neuroanat 14:1-19. CrossRef Medline

Defelipe J, González-Albo MC, Del Río MR, Elston GN (1999) Distribution and patterns of connectivity of interneurons containing calbindin, calretinin, and parvalbumin in visual areas of the occipital and temporal lobes of the macaque monkey. J Comp Neurol 412:515-526. CrossRef Medline

Deng YP, Shelby E, Reiner AJ (2010) Immunohistochemical localization of AMPA-type glutamate receptor subunits in the striatum of rhesus monkey. Brain Res 1344:104-123. CrossRef Medline

Dingledine R, Borges K, Bowie D, Traynelis SF (1999) The glutamate receptor ion channels. Pharmacol Rev 51:7-61. Medline

Disney AA, Aoki C (2008) Muscarinic acetylcholine receptors in macaque $\mathrm{V} 1$ are most frequently expressed by parvalbumin-immunoreactive neurons. J Comp Neurol 507:1748-1762. CrossRef Medline

Greger IH, Khatri L, Ziff EB (2002) RNA editing at arg607 controls AMPA receptor exit from the endoplasmic reticulum. Neuron 34:759-772. CrossRef Medline

He Y, Hof PR, Janssen WG, Vissavajjhala P, Morrison JH (2001) AMPA GluR2 subunit is differentially distributed on GABAergic neurons and pyramidal cells in the macaque monkey visual cortex. Brain Res 921:6067. CrossRef Medline

Helmchen F, Imoto K, Sakmann B (1996) Ca2+ buffering and action potential-evoked $\mathrm{Ca} 2+$ signaling in dendrites of pyramidal neurons. Biophys J 70:1069-1081. CrossRef Medline

Hofer SB, Ko H, Pichler B, Vogelstein J, Ros H, Zeng H, Lein E, Lesica NA, Mrsic-Flogel TD (2011) Differential connectivity and response dynamics of excitatory and inhibitory neurons in visual cortex. Nat Neurosci 14:1045-1052. CrossRef Medline

Hull C, Isaacson JS, Scanziani M (2009) Postsynaptic mechanisms govern the differential excitation of cortical neurons by thalamic inputs. J Neurosci 29:9127-9136. CrossRef Medline

Isaacson JS, Scanziani M (2011) How inhibition shapes cortical activity. Neuron 72:231-243. CrossRef Medline

Jones EG (1984) Neurogliaform or spiderweb cells. In: Cerebral cortex (Peters A, Jones EG, eds), pp 409-418. New York: Plenum.

Kaiser KM, Zilberter Y, Sakmann B (2001) Back-propagating action potentials mediate calcium signalling in dendrites of bitufted interneurons in layer $2 / 3$ of rat somatosensory cortex. J Physiol 535:17-31. CrossRef Medline
Kessels HW, Malinow R (2009) Synaptic AMPA receptor plasticity and behavior. Neuron 61:340-350. CrossRef Medline

Kessels HW, Kopec CD, Klein ME, Malinow R (2009) Roles of stargazin and phosphorylation in the control of AMPA receptor subcellular distribution. Nat Neurosci 12:888-896. CrossRef Medline

Kim TJ, Ye EA, Jeon CJ (2006) Distribution of AMPA glutamate receptor GluR1 subunit-immunoreactive neurons and their co-localization with calcium-binding proteins and GABA in the mouse visual cortex. Mol Cells 21:34-41. Medline

Kisvarday ZF, Cowey A, Somogyi P (1986) Synaptic relationships of a type of GABA-immunoreactive neuron (clutch cell), spiny stellate cells and lateral geniculate nucleus afferents in layer IVC of the monkey striate cortex. Neuroscience 19:741-761. CrossRef Medline

Kisvárday ZF, Gulyas A, Beroukas D, North JB, Chubb IW, Somogyi P (1990) Synapses, axonal and dendritic patterns of GABA-immunoreactive neurons in human cerebral cortex. Brain 113:793-812. CrossRef Medline

Koester HJ, Sakmann B (2000) Calcium dynamics associated with action potentials in single nerve terminals of pyramidal cells in layer $2 / 3$ of the young rat neocortex. J Physiol 529:625-646. CrossRef Medline

Koike M, Iino M, Ozawa S (1997) Blocking effect of 1-naphthyl acetyl spermine on $\mathrm{Ca}(2+)$-permeable AMPA receptors in cultured rat hippocampal neurons. Neurosci Res 29:27-36. CrossRef Medline

Lee SH, Rosenmund C, Schwaller B, Neher E (2000) Differences in Ca2+ buffering properties between excitatory and inhibitory hippocampal neurons from the rat. J Physiol 525:405-418. CrossRef Medline

Lerma J, Morales M, Ibarz JM, Somohano F (1994) Rectification properties and $\mathrm{Ca} 2+$ permeability of glutamate receptor channels in hippocampal cells. Eur J Neurosci 6:1080-1088. CrossRef Medline

Leuschner WD, Hoch W (1999) Subtype-specific assembly of alpha-amino3-hydroxy-5-methyl-4-isoxazole propionic acid receptor subunits is mediated by their n-terminal domains. J Biol Chem 274:16907-16916. CrossRef Medline

Li YT, Ma WP, Li LY, Ibrahim LA, Wang SZ, Tao HW (2012) Broadening of inhibitory tuning underlies contrast-dependent sharpening of orientation selectivity in mouse visual cortex. J Neurosci 32:16466-16477. CrossRef Medline

Lund JS (1987) Local circuit neurons of macaque monkey striate cortex: I. Neurons of laminae 4C and 5A. J Comp Neurol 257:60-92. CrossRef Medline

Lund JS, Wu CQ (1997) Local circuit neurons of macaque monkey striate cortex: IV. Neurons of laminae 1-3A. J Comp Neurol 384:109-126. CrossRef Medline

Lund JS, Yoshioka T (1991) Local circuit neurons of macaque monkey striate cortex: III. Neurons of laminae 4B, 4A, and 3B. J Comp Neurol 311: 234-258. CrossRef Medline

Lund JS, Hawken MJ, Parker AJ (1988) Local circuit neurons of macaque monkey striate cortex: II. Neurons of laminae 5B and 6. J Comp Neurol 276:1-29. CrossRef Medline

Martin LJ, Blackstone CD, Levey AI, Huganir RL, Price DL (1993) Cellular localizations of AMPA glutamate receptors within the basal forebrain magnocellular complex of rat and monkey. J Neurosci 13:2249-2263. Medline

Mascagni F, Muly EC, Rainnie DG, McDonald AJ (2009) Immunohistochemical characterization of parvalbumin-containing interneurons in the monkey basolateral amygdala. Neuroscience 158:1541-1550. CrossRef Medline

Moga DE, Janssen WG, Vissavajjhala P, Czelusniak SM, Moran TM, Hof PR, Morrison JH (2003) Glutamate receptor subunit 3 (GluR3) immunoreactivity delineates a subpopulation of parvalbumin-containing interneurons in the rat hippocampus. J Comp Neurol 462:15-28. CrossRef Medline

Montgomery KE, Kessler M, Arai AC (2009) Modulation of agonist binding to AMPA receptors by 1-(1,4-benzodioxan-6-ylcarbonyl)piperidine (CX546): differential effects across brain regions and GluA1-4/transmembrane AMPA receptor regulatory protein combinations. J Pharmacol Exp Ther 331:965-974. CrossRef Medline

Monyer H, Fuchs E, Meyer A, Traub R, Doheny H, Faulkner HJ, Whittington MA (2000) AMPA receptor diversity and regulation thereof in identified neurons. Eur J Neurosci 12:517.

Morrow BA, Elsworth JD, Roth RH (2007) Repeated phencyclidine in monkeys results in loss of parvalbumin-containing axo-axonic projections in 
the prefrontal cortex. Psychopharmacology (Berl) 192:283-290. CrossRef Medline

Nieuwenhuys R, Voogd J, Huijzen C van (2007) The human central nervous system: a synopsis and atlas. Amsterdam: Steinkopff.

Pinheiro Botelho E, Guimarães Martins Soares J, da Silva Pereira S, Fiorani M, Gattass R (2006) Distribution of calbindin-28kD and parvalbumin in V1 in normal adult Cebus apella monkeys and in monkeys with retinal lesions. Brain Res 1117:1-11. CrossRef Medline

Povysheva NV, Zaitsev AV, Kröner S, Krimer OA, Rotaru DC, GonzalezBurgos G, Lewis DA, Krimer LS (2007) Electrophysiological differences between neurogliaform cells from monkey and rat prefrontal cortex. J Neurophysiol 97:1030-1039. Medline

Povysheva NV, Zaitsev AV, Rotaru DC, Gonzalez-Burgos G, Lewis DA, Krimer LS (2008) Parvalbumin-positive basket interneurons in monkey and rat prefrontal cortex. J Neurophysiol 100:2348-2360. CrossRef Medline

Ryoo SR, Ahn CH, Lee JY, Kang YS, Jeon CJ (2003) Immunocytochemical localization of neurons containing the AMPA GluR2/3 subunit in the hamster visual cortex. Mol Cells 16:211-215. Medline

Strømgaard K, Jensen LS, Vogensen SB (2005) Polyamine toxins: development of selective ligands for ionotropic receptors. Toxicon 45:249-254. CrossRef Medline

Swanson GT, Kamboj SK, Cull-Candy SG (1997) Single-channel properties of recombinant AMPA receptors depend on RNA editing, splice variation, and subunit composition. J Neurosci 17:58-69. Medline
The UniProt Consortium (2010) The Universal Protein Resource (UniProt) in 2010. Nucleic Acids Res 38:D142-D148. CrossRef Medline

Tricoire L, Pelkey KA, Erkkila BE, Jeffries BW, Yuan X, McBain CJ (2011) A blueprint for the spatiotemporal origins of mouse hippocampal interneuron diversity. J Neurosci 31:10948-10970. CrossRef Medline

Van Brederode JF, Mulligan KA, Hendrickson AE (1990) Calcium-binding proteins as markers for subpopulations of GABAergic neurons in monkey striate cortex. J Comp Neurol 298:1-22. CrossRef Medline

Wenthold RJ, Petralia RS, Blahos J II, Niedzielski AS (1996) Evidence for multiple AMPA receptor complexes in hippocampal CA1/CA2 neurons. J Neurosci 16:1982-1989. Medline

Wouterlood FG (2005) 3-D reconstruction of neurons from multichannel confocal laser scanning image series. Curr Protoc Neurosci, Chapter 2, Unit 2.8. CrossRef Medline

Wouterlood FG, Boekel AJ, Kajiwara R, Beliën JA (2008) Counting contacts between neurons in 3D in confocal laser scanning images. J Neurosci Methods 171:296-308. CrossRef Medline

Zaitsev AV, Gonzalez-Burgos G, Povysheva NV, Kröner S, Lewis DA, Krimer LS (2005) Localization of calcium-binding proteins in physiologically and morphologically characterized interneurons of monkey dorsolateral prefrontal cortex. Cereb Cortex 15:1178-1186. Medline

Zhu JJ, Esteban JA, Hayashi Y, Malinow R (2000) Postnatal synaptic potentiation: delivery of GluR4-containing AMPA receptors by spontaneous activity. Nat Neurosci 3:1098-1106. CrossRef Medline 